\title{
Erratum to: Child Welfare Involvement of Mothers with Mental Health Issues
}

\author{
Callie Westad · David McConnell
}

Published online: 27 March 2011

(C) Springer Science+Business Media, LLC 2011

\section{Erratum to: Community Ment Health J}

DOI 10.1007/s10597-011-9374-0

An error was notified in the published article. While discussing maternal mental health issues under the heading
"Child Welfare Investigation Outcomes" the reader is directed to Table 2 erroneously, when they should be directed to Table 4.

The online version of the original article can be found under doi:10.1007/s10597-011-9374-0.

C. Westad · D. McConnell ( $₫)$

Department of Occupational Therapy, Faculty of Rehabilitation Medicine, University of Alberta, 3-66 Corbett Hall, Edmonton, AB T6G 2G4, Canada

e-mail: david.mcconnell@ualberta.ca 